\title{
Sintesis dan Pencirian Poli(etilena glikol) bermetoksi-ko-Poli( $\beta$-amino ester) yang Dibentuk daripada Heksilamina Linear dan Siklik Sebagai Misel Polimer
}

(Synthesis and Characterization of Methoxy Poly(ethylene glycol)-co-poly( $\beta$-amino ester) formed by Linear and Cyclic Hexylamines as Polymeric Micelles)

\author{
Jia-Chyi Wong, Chin-Hua ChiA*, SweE-Yee Chin, Poi-Sim KHIEW \& SARANi ZaKaria
}

\begin{abstract}
ABSTRAK
Poli(etilena glikol) bermetoksi-ko-poli( $\beta$-amino ester) (MPEG-PbAE) telah disintesis dengan menggunakan poli(etilena glikol) bermetoksi yang mempunyai kumpulan hujung berfungsi akrilat (MPEG-ac), 1,6-heksanadiol diakrilat, heksilamina linear (A) dan heksilamina siklik (B) sebagai bahan reaktan. Kopolimer MPEG-PbAE A dan B dijangka akan membentuk misel dengan MPEG berfungsi sebagai bahagian luar yang hidrofilik dan PbAE yang mempunyai kumpulan heksil berfungsi sebagai bahagian dalam yang hidrofobik. MPEG-ac selepas diubah suai dan kopolimer MPEG-PbAE A dan B selepas disintesis telah dicirikan. Spektroskopi inframerah transformasi Fourier (FT-IR) dan spektroskopi resonans magnet nukleus jenis proton $\left({ }^{1} H\right.$-NMR) telah mengesahkan pengubahsuaian kumpulan hujung hidroksil di MPEG kepada kumpulan hujung akrilat. Didapati kopolimer A adalah lebih sesuai digunakan sebagai pembawa ubat berdasarkan perbandingan antara kopolimer A daripada heksilamina linear dan kopolimer B daripada heksilamina siklik. Kromatografi penelapan gel (GPC) menunjukkan bahawa nombor-purata berat molekul, $M_{n}$ kopolimer A adalah 11216 dengan indeks kepoliserakan (PDI) 1.1925. Kepekatan misel kritikal (CMC) kopolimer A dalam larutan akueus pH7.4 adalah 84.6 mg/L. Purata saiz misel yang diperoleh daripada analisis penyerakan cahaya dinamik (DLS) adalah $26.25 \pm 0.149 \mathrm{~nm}$.
\end{abstract}

Kata kunci: Heksilamina; misel polimer; poli(etilena glikol) bermetoksi-ko-poli( $\beta$-amino ester)

\section{ABSTRACT}

Methoxy poly(ethylene glycol)-co-poly( $\beta$-amino ester) (MPEG-PbAE) was synthesized using pre-modified acrylated-end methoxy poly(ethylene glycol) (MPEG-ac), 1,6-hexanediol diacrylate, linear hexylamine ( $A$ ) and cyclic hexylamine (B) as reactants. The MPEG-PbAE copolymer $A$ and $B$ were expected to form micelles where MPEG acts as the hydrophilic shell and the PbAE with hexyl groups acts as the hydrophobic core. The modified MPEG-ac, synthesized MPEG-PbAE copolymer $A$ and $B$ were then characterized. The Fourier transformed infrared spectroscopy (FT-IR) and proton nuclear magnetic resonance spectroscopy $\left({ }^{1} \mathrm{H}\right.$-NMR) confirmed the modification of hydroxyl end group of MPEG to acrylate end group. It was found that the copolymer A is more suitable as drug carrier by the comparison between copolymer A formed by linear hexylamine and copolymer B formed by cyclic hexylamine. Gel permeation chromatography (GPC) showed that the number average molecular weight, $M_{n}$ of the copolymer $A$ was 11216 with polydispersity index (PDI) 1.1925. The critical micelle concentration (CMC) of copolymer A in aqueous solution at pH7.4 is $84.6 \mathrm{mg} / \mathrm{L}$. The average micellar size that are obtained from dynamic light scattering (DLS) analysis was $26.25 \pm 0.149 \mathrm{~nm}$.

Keywords: Hexylamine; methoxy poly(ethylene glycol)-co-poly( $\beta$-amino ester $) ;$ polymeric micelles

\section{PENGENALAN}

Misel polimer telah digunakan dalam aplikasi bioperubatan secara meluas terutamanya dalam penyampaian ubat antikanser yang bersifat hidrofobik. Saiz misel polimer yang kecil (<100 nm) dapat membantu dalam penujuan ubat ke tapak patologi sasaran seperti tumor secara pasif melalui kesan peningkatan penelapan dan penahanan (EPR) (Ayre et al. 2013; Cho et al. 2014; Kwon \& Okano 1996; Zhang et al. 2014). Polimer yang kerap dipilih untuk lapisan luar misel yang bersifat hidrofilik ialah poli(etilena glikol) (PEG) kerana ia mempunyai keupayaan untuk menyembunyikan diri daripada sistem mononuklear-fagosit (MPS) dalam badan manusia (Hoffman \& Pun 2012). Dengan keupayaan ini, masa pengedaran misel polimer yang mengandungi PEG dalam saluran darah badan kita akan dipanjangkan. Di samping itu, kepelbagaian kumpulan hujung dalam PEG yang sedia ada secara komersial dalam pasaran juga telah meningkatkan peluang untuk mengubahsuai bahagian hidrofobik dalam misel polimer.

Poli( $\beta$-amino ester $)$, PbAE pertama disintesis oleh kumpulan Langer melalui penambahan kumpulan amina ke atas kumpulan reaktif akrilat pada tahun 2000 (Lynn \& Langer 2000). Mereka mensintesiskan pelbagai jenis $\mathrm{PbAE}$ dengan struktur yang unik untuk menguji sifatnya dalam aplikasi penyampaian gen (Akinc et al. 2003; Lynn et al. 2001). Disebabkan oleh pilihan monomer amina 
dan akrilat yang banyak, monomer dengan kumpulan alkil yang lebih besar dapat dipilih untuk membentuk $\mathrm{PbAE}$ dengan sifat hidrofobik. Sebagai contoh, kumpulan Lee telah mensintesiskan kopolimer MPEG-PbAE dengan menggunakan 1,6-heksanadiol diakrilat dan 4,4'-trimetilenadipiperidina sebagai monomer PbAE yang bersifat hidrofobik. Mereka menggunakan kopolimer tersebut dalam penyampaian ubat hidrofobik. Selain daripada ini, misel polimer yang dibentuk mempunyai sifat kepekaan kepada $\mathrm{pH}$ disebabkan oleh kehadiran kumpulan amina tertier dalam $\mathrm{PbAE}$ yang dapat diprotonkan pada $\mathrm{pH}$ rendah. Sifat ini membantu dalam pelepasan ubat secara terkawal di tapak sasaran tertentu dalam badan manusia (Kim et al. 2006; Ko et al. 2007; Min et al. 2010; Wu et al. 2010).

Dalam kajian ini, monomer akrilat iaitu 1,6-heksanadiol diakrilat digunakan untuk bertindak balas dengan heksilamina linear atau heksilamina siklik yang berfungsi sebagai monomer amina. Bahan-bahan reaktan ini dicampurkan dengan MPEG-ac untuk menghasilkan kopolimer MPEG-PbAE A dan B. Kedua-dua monomer ini mempunyai kumpulan heksil sebagai moieti hidrofobik. Ciri-ciri seperti berat molekul, kepekatan misel kritikal dan purata saiz misel bagi kopolimer yang terhasil telah dikaji.

\section{BAHAN DAN KAEDAH}

\section{BAHAN KIMIA}

Poli(etilena glikol) bermetoksi (MPEG-OH, purata $\mathbf{M}_{n}$ 5000 ), trietilamina (TEA, $\geq 99 \%$ ), sikloheksilamina (99\%) dan 1,6-heksanadiol diakrilat (1,6-HDD, 80\%) dibeli dari Sigma Aldrich. N-heksilamina (99\%) diperoleh dari Acros Organics. Akriloil klorida (Ac.Cl, $\geq 96 \%$ ), diklorometana kering (DCM), kloroform kering, n-heksana, dietil eter dan asid hidroklorik $(\mathrm{HCl})$ dibeli dari Merck. Setiap bahan kimia digunakan tanpa penulenan.
SINTESIS POLI(ETILENA GLIKOL) BERMETOKSI DENGAN KUMPULAN HUJUNG AKRILAT, MPEG-ac

MPEG-OH dengan purata Mn 5000 (1 eq.) telah ditimbang di dalam kelalang bulat berleher tiga dan berwarna ambar. Gas nitrogen dialirkan ke dalam kelalang bulat tersebut selama 30 min untuk menyingkirkan kelembapan. Selepas itu, trietilamina (2 eq.) dalam DCM kering pula ditambah. Campuran dikacau dengan pengacau magnet dan disejukkan dengan cecair pendingin sehingga $0^{\circ} \mathrm{C}$. Setelah MPEG-OH dilarutkan sepenuhnya, Ac.Cl (1.5 eq.) dalam DCM kering ditambahkan ke dalam kelalang bulat dengan perlahan serta pengacauan dilakukan secara serentak. Tindak balas dijalankan pada $0^{\circ} \mathrm{C}$ selama 2 jam, dibiarkan untuk mencapai suhu $25^{\circ} \mathrm{C}$ selama 3 jam dan dikekalkan pada suhu $25^{\circ} \mathrm{C}$ selama 24 jam dalam perlindungan gas nitrogen. Semua reaktan cecair dipindah dengan menggunakan kanula. Larutan asid $\mathrm{HCl}$ cair diguna untuk mengekstrakkan campuran sebanyak dua kali. Fasa organik iaitu lapisan DCM telah dipekatkan dengan pengewap putaran dan kemudian dititis ke dalam n-heksana yang dikacau dengan laju. Produk iaitu MPEGac akan termendak di dalam n-heksana dan mendakan ini dikeringkan secara vakum.

\section{SINTESIS POLI(ETILENA GLIKOL) BERMETOKSI-KO- POLI $(\beta$-AMINO ESTER), MPEG-PbAE}

MPEG-ac ditimbangkan di dalam dua vial ambar yang berisi padu $40 \mathrm{~mL}$ dan dilabel A dan B. Kloroform kering diguna untuk melarutkan MPEG-ac dalam vial dan 1,6-heksanadiol diakrilat ditambah sebagai monomer akrilat. Monomer amina iaitu $\mathrm{n}$-heksilamina dan sikloheksilamina ditambahkan ke dalam vial A dan vial B masing-masing. Nisbah molar MPEG-ac: 1,6-HDD: heksilamina adalah 1: 10: 10. Campuran dikacau dengan pengacau magnet dalam oven pada suhu $60^{\circ} \mathrm{C}$ selama dua hari. Dietil eter diguna untuk memendakkan produk iaitu MPEG-PbAE A dan B. Produk dikeringkan secara vakum sebelum disimpan pada suhu $-20^{\circ} \mathrm{C}$. Rajah 1 menunjukkan penjelasan skematik

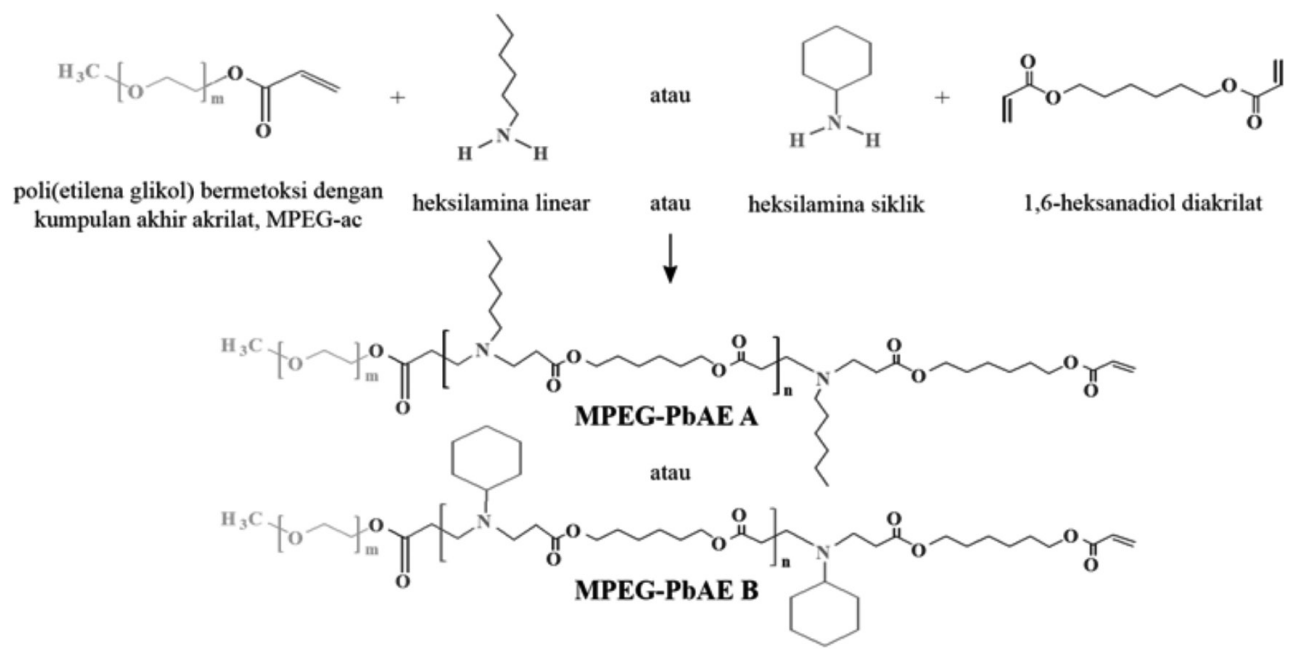

RAJAH 1. Tindak balas untuk mensintesiskan kopolimer MPEG-PbAE A dan B 
bagi tindak balas untuk mensintesiskan kopolimer MPEG$\mathrm{PbAE} A$ dan $\mathrm{B}$.

\section{PENCIRIAN}

Spektroskopi inframerah transformasi Fourier (Perkin Elmer Spectrum 400 FT-IR) diguna untuk menentukan kumpulan berfungsi yang wujud pada polimer MPEG-OH dan MPEG-ac sebelum dan selepas tindak balas. Julat nombor gelombang adalah daripada 4000 hingga $650 \mathrm{~cm}^{-1}$. Spektroskopi resonans magnet nukleus jenis proton $\left({ }^{1} \mathrm{H}\right.$-NMR, Bruker/AVANCE III $\left.600 \mathrm{MHz}\right)$ diguna untuk mengenal pasti struktur polimer. Polimer sebanyak $20 \mathrm{mg}$ dilarutkan dalam $600 \mu \mathrm{L}$ pelarut kloroform berdeuterium $\left(\mathrm{CDCl}_{3}\right)$ untuk diuji dengan spektroskopi ${ }^{1} \mathrm{H}$-NMR. Di samping itu, purata berat molekul relatif kopolimer dan indeks kepoliserakan (PDI) ditentukan dengan kromatografi penelapan gas (GPC, Waters Corporation) dilengkapi dengan turus Styragel HRl, HR3 dan HR5 yang disambung secara siri. Polimer sebanyak $5 \mathrm{mg}$ dilarutkan dalam pelarut THF sebanyak $5 \mathrm{~mL}$. Sampel sebanyak $50 \mu \mathrm{L}$ disuntik ke dalam sistem dan kadar aliran sebanyak $1 \mathrm{~mL} / \mathrm{min}$ digunakan. Data dianalisis oleh pengesan indeks biasan (Waters 2414 Refractive Index Detector). Spektrofotometer pendarfluor (Agilent Cary Eclipse) pula membantu dalam penentuan kepekatan misel kritikal (CMC) dengan menggunakan pirena sebagai prob pendarfluor. Larutan polimer disediakan dalam julat kepekatan 0.1 hingga $250 \mathrm{mg} / \mathrm{L}$. Purata saiz misel ditentukan melalui analisis penyerakan cahaya dinamik (DLS, Malvern Zetasizer Nano-ZS). Sampel iaitu misel polimer dalam larutan akueus diisi ke dalam kuvet dan diletakkan pada pemegang sampel mesin. Selepas itu, pengukuran saiz diambil pada suhu $25^{\circ} \mathrm{C}$.

\section{KEPUTUSAN DAN PERBINCANGAN}

\section{SINTESIS POLI(ETILENA GLIKOL) BERMETOKSI DENGAN} KUMPULAN HUJUNG AKRILAT, MPEG-AC

Penentuan Struktur MPEG-ac daripada Spektroskopi ${ }^{1} H$-NMR dan FT-IR Rajah 2(a) menunjukkan spektrum ${ }^{1} \mathrm{H}$-NMR bagi polimer MPEG sebelum dan selepas tindak balas. Kedua-dua spektrum mempunyai satu puncak yang dilabel ' $a$ ' pada 2.6 ppm dengan puncak tersebut mewakili atom-atom $\mathrm{H}$ dalam kumpulan metoksi yang wujud dalam kedua-dua MPEG-OH dan MPEG-ac. Isyarat ' $b$ ' dari 3.3 hingga 3.7 ppm menandakan atom-atom $\mathrm{H}$ yang wujud dalam etilena glikol manakala isyarat ' $c$ ' iaitu $4.3 \mathrm{ppm}$ dalam spektrum MPEG-ac adalah tanda bagi atom $\mathrm{H}$ dalam etilena glikol yang paling dekat dengan kumpulan akrilat. Puncak ' $d, e, f$ ' yang hanya dapat diperhatikan dalam spektrum MPEG-ac mewakili atom $\mathrm{H}$ yang berikatan dengan $\mathrm{C}=\mathrm{C}$ dalam kumpulan akrilat. Puncak tersebut tidak muncul dalam spektrum MPEG-OH sebelum tindak balas. Analisis ${ }^{1} \mathrm{H}$-NMR bagi pengubahsuaian kumpulan hidroksil kepada kumpulan akrilat pernah dilaporkan oleh Hwang et al. (2007).

Spektrum FT-IR bagi polimer MPEG-OH dan MPEG-ac telah ditunjukkan dalam Rajah 2(b). Terdapat tiga jalur serapan yang hanya muncul dalam spektrum MPEG-ac. Jalur serapan pertama pada $1723 \mathrm{~cm}^{-1}$ adalah disebabkan oleh regangan $\mathrm{C}=\mathrm{O}$ dalam kumpulan ester daripada akrilat. Jalur serapan antara $1600-1680 \mathrm{~cm}^{-1}$ mewakili regangan $\mathrm{C}=\mathrm{C}$ di hujung kumpulan akrilat manakala jalur serapan pada $1194 \mathrm{~cm}^{-1}$ menandakan kehadiran ikatan kimia C-O yang terdapat dalam kumpulan hujung akrilat (Stuart 2004).

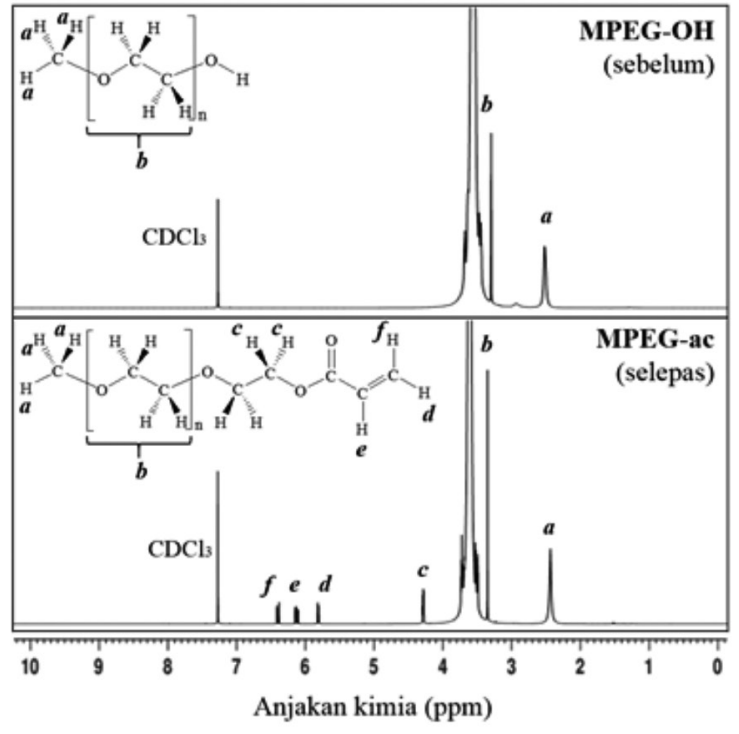

(a)

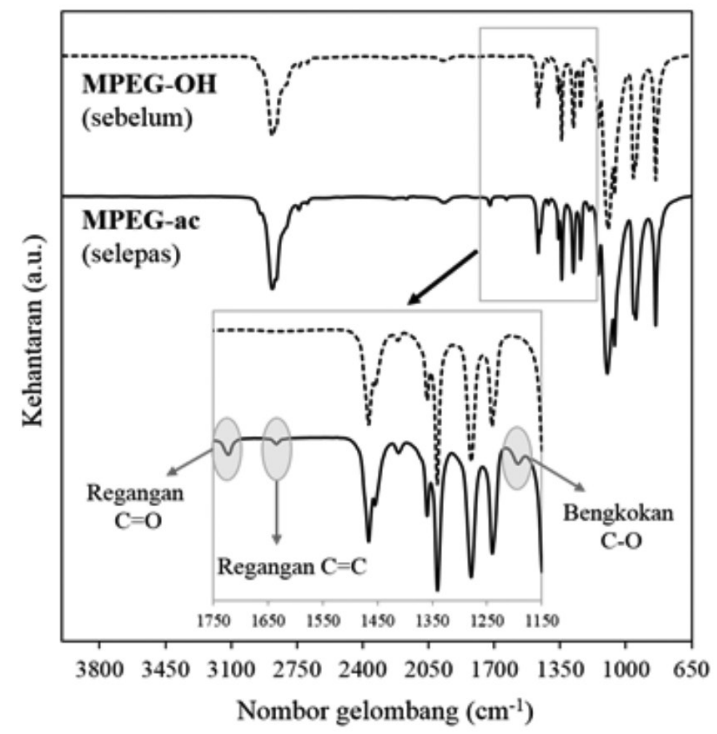

(b)

RAJAH 2. (a) Spektrum ${ }^{1} \mathrm{H}-\mathrm{NMR}$ bagi polimer MPEG-OH dan MPEG-ac dan

(b) Spektrum FT-IR bagi polimer MPEG-OH dan MPEG-ac 
Perbezaan dalam spektrum ${ }^{1} \mathrm{H}-\mathrm{NMR}$ dan FT-IR bagi MPEG sebelum dan selepas tindak balas menunjukkan bahawa pengubahsuaian kumpulan berfungsi hujung hidroksil kepada akrilat telah berlaku dan MPEG-ac yang telah disintesis dapat digunakan dalam prosedur seterusnya.

\section{SINTESIS POLI(ETILENA GLIKOL) BERMETOKSI-KO-POLI ( $\beta$-AMINO ESTER), MPEG-PBAE}

Penentuan Berat Molekul MPEG-PbAE daripada Analisis $G P C$ Untuk mengetahui purata berat molekul relatif bagi kopolimer MPEG-PbAE A dan B, kromatografi GPC telah digunakan. Polistirena berfungsi sebagai standard penentukuran dalam analisis GPC. Rajah 3 menunjukkan kromatogram bagi kopolimer MPEG-PbAE A dan B. Purata berat molekul relatif bagi kopolimer MPEG-PbAE A dinyatakan seperti berikut: $M_{n}=11216, M_{w}=13375$,
$M_{p}=13046$ dengan indeks kepoliserakan, $\mathrm{PDI}=1.1925$ dengan $M_{n}$ ialah nombor-purata berat molekul, $M_{w}$ ialah berat-purata berat molekul dan $\mathrm{M}_{\mathrm{p}}$ ialah berat molekul pada puncak spektrum. Bagi kopolimer MPEG-PbAE B pula, purata berat molekul relatif adalah seperti berikut: $M_{n}=10722, M_{w}=12864, M_{P}=13037$ dengan indeks kepoliserakan, PDI=1.1998. Kedua-dua kopolimer mempunyai purata berat molekul relatif yang tidak jauh berbeza kerana jisim molar bagi monomer heksilamina linear dan heksilamina siklik adalah hampir sama.

Penentuan Kepekatan Misel Kritikal MPEG-PbAE daripada Spektroskopi Pendarfluor Kepekatan misel kritikal, CMC memainkan peranan yang penting dalam menentukan kestabilan sesuatu misel polimer dalam keadaan fisiologi. Pencairan kopolimer dalam medium fisiologi seperti darah sampai ke satu tahap dengan kepekatannya lebih rendah daripada CMC yang akan

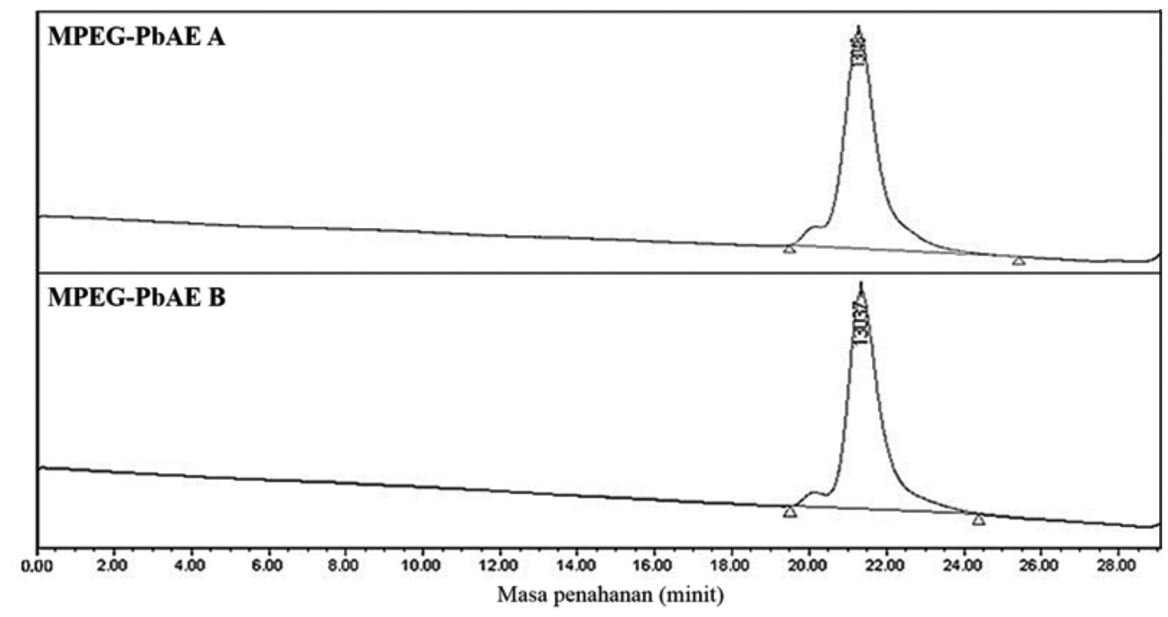

RAJAH 3. Kromatogram GPC bagi kopolimer MPEG-PbAE A dan B

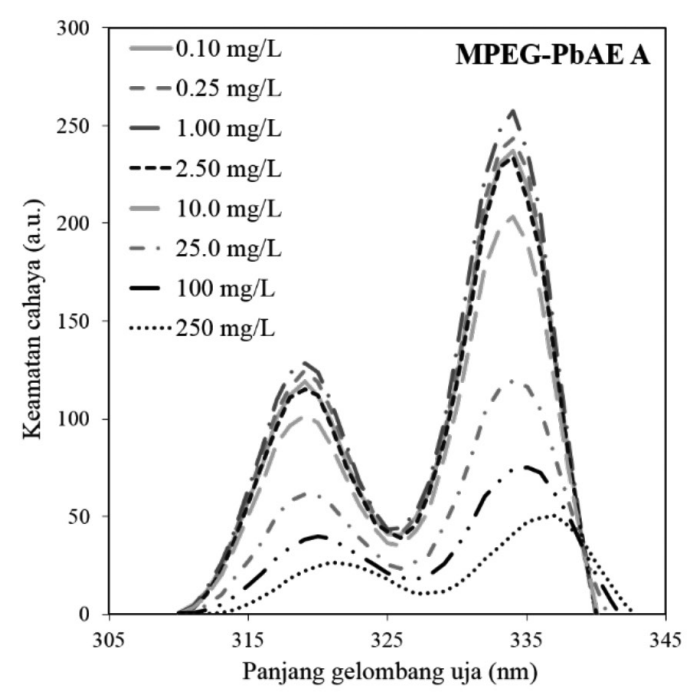

(a)

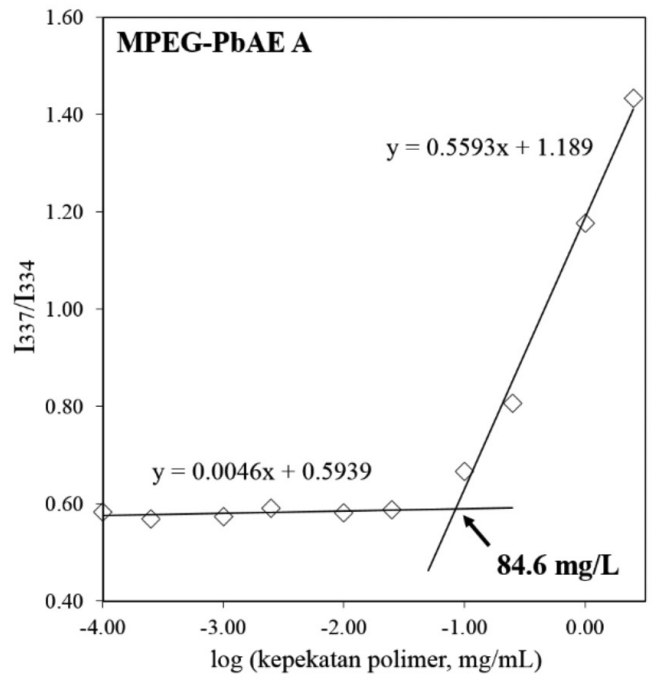

(b)

RAJAH 4. (a) Spektrum pengujaan oleh pirena dalam larutan kopolimer yang berkepekatan berlainan pada panjang gelombang pancaran 395 nm dan (b) Graf nisbah keamatan cahaya $\mathrm{I}_{337} / \mathrm{I}_{334}$ melawan $\log ($ kepekatan polimer, mg/mL) bagi kopolimer MPEG-PbAE A 


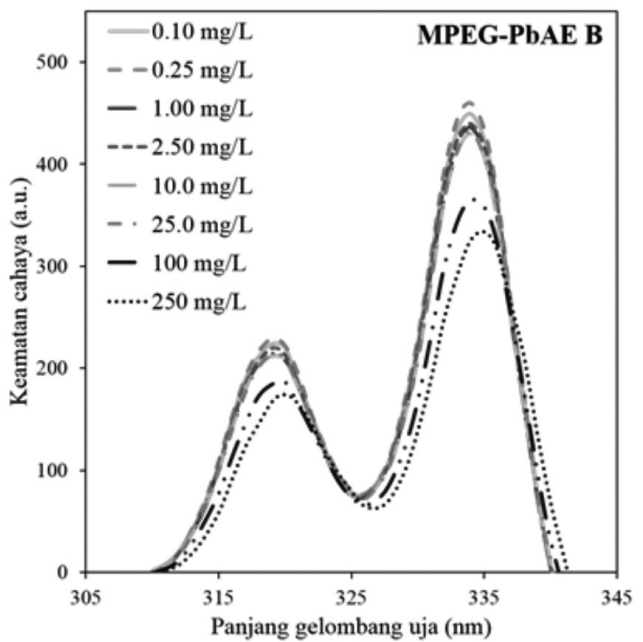

(a)

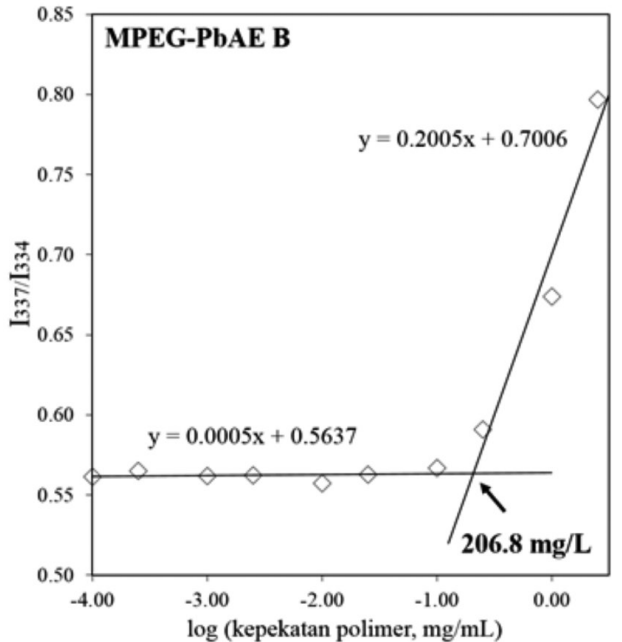

(b)

RAJAH 5. (a) Spektrum pengujaan oleh pirena dalam larutan kopolimer yang berkepekatan berlainan pada panjang gelombang pancaran $395 \mathrm{~nm}$ dan (b) Graf nisbah keamatan cahaya $\mathrm{I}_{337} / \mathrm{I}_{334}$ melawan $\log ($ kepekatan polimer, $\mathrm{mg} / \mathrm{mL}$ ) bagi kopolimer MPEG-PbAE B

menyebabkan penceraian misel polimer dan pelepasan kandungan dalam misel secara tidak terkawal (Zhao et al. 2010). Rajah 4(a) dan 5(a) merupakan spektrum pengujaan yang telah direkod daripada panjang gelombang uja 305 hingga $345 \mathrm{~nm}$ pada panjang gelombang pancaran $395 \mathrm{~nm}$ bagi kopolimer MPEG-PbAE A dan B. Apabila kepekatan kopolimer semakin meningkat, puncak maksimum akan beranjak dari 334 kepada 337 nm. Anjakan ini membawa maksud bahawa persekitaran di sekeliling pirena telah bertukar daripada keadaan yang berkutub kepada keadaan yang tidak berkutub (Peng et al. 2013). Perubahan ini menunjukkan bahawa misel polimer sudah mula terbentuk dengan peningkatan kepekatan kopolimer dalam larutan akueus. Pirena yang hidrofobik adalah lebih gemar untuk berada dalam teras misel daripada berada dalam larutan akueus secara bebas. Menurut graf nisbah keamatan cahaya $\mathrm{I}_{337} / \mathrm{I}_{334}$ melawan $\log$ (kepekatan polimer, $\mathrm{mg} / \mathrm{mL}$ ) bagi kopolimer A dan B dalam Rajah 4(b) dan 5(b), nilai CMC telah didapati daripada titik persilangan dua garis lulus dalam graf (Bui et al. 2015). Nilai CMC bagi kopolimer A ialah $84.6 \mathrm{mg} / \mathrm{L}$ manakala bagi kopolimer B ialah $206.8 \mathrm{mg} / \mathrm{L}$ dalam larutan akueus pada $\mathrm{pH} 7.4$.

Penentuan Purata Saiz Misel MPEG-PbAE daripada Analisis DLS Misel polimer yang terbentuk daripada kopolimer biasanya mempunyai saiz lebih kecil dari 100 nm (Kwon \& Okano 1996; Lavasanifar et al. 2002). Misel dengan saiz yang begitu kecil adalah lebih susah untuk dikesan oleh sistem imun badan manusia jika dibandingkan dengan saiz partikel yang lebih besar. Selain itu, misel saiz kecil juga lebih mudah untuk diekstravasat ke dalam tapak tumor melalui kesan peningkatan penelapan dan penahanan (EPR) (Gaucher et al. 2005; Movassaghian et al. 2015). Dalam kajian ini, saiz misel yang terbentuk daripada kopolimer MPEG-PbAE A dan B telah diuji. Berdasarkan Rajah 6, kami mendapati bahawa kopolimer A dapat membentuk misel dalam satu taburan saiz yang lebih sekata berbanding kopolimer B. Purata saiz misel yang terbentuk daripada kopolimer MPEG-PbAE A adalah sebanyak 26.25 $\pm 0.149 \mathrm{~nm}$. Bagi kopolimer MPEG-PbAE B, taburan saiz yang dapat diperhatikan adalah tidak sekata. Ketiga-tiga purata saiz yang diperoleh adalah $5.120 \pm 0.079,72.31 \pm 5.692$ dan $1016 \pm 152.3 \mathrm{~nm}$. Saiz yang melebihi $1000 \mathrm{~nm}$ berkemungkinan besar disebabkan oleh penggumpalan kopolimer B atau misel polimer yang terbentuk daripada kopolimer B. Keadaan ini menyebabkan kopolimer B tidak sesuai sebagai pembawa ubat kerana kemungkinannya untuk bergumpal di dalam darah.

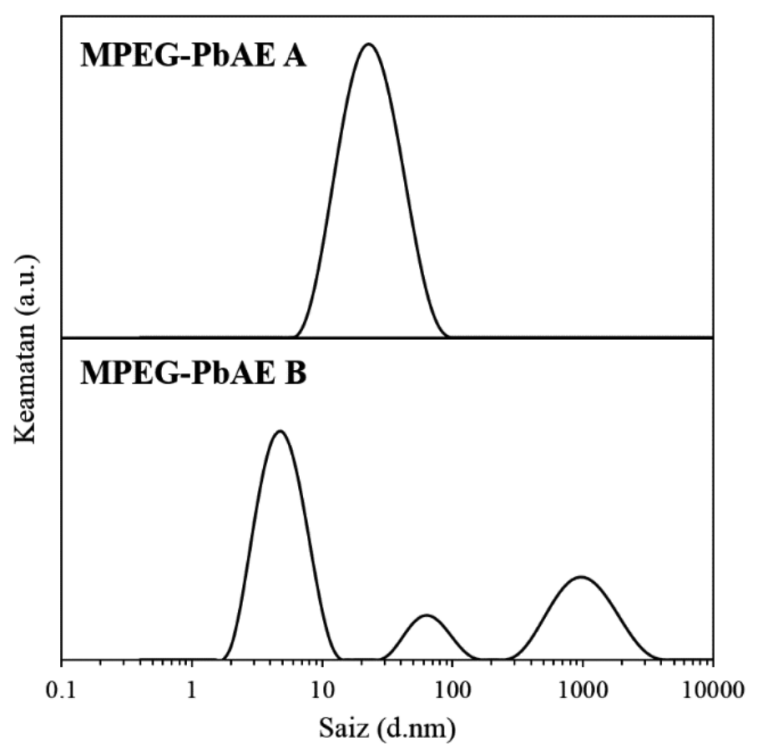

RAJAH 6. Graf taburan saiz bagi misel daripada kopolimer MPEG-PbAE A dan B 


\section{KESIMPULAN}

Dalam kajian ini, MPEG-ac telah berjaya dihasil dan digunakan sebagai reaktan dalam sintesis kopolimer MPEG-PbAE dan strukturnya telah dikenalpastikan dengan analisis spektroskopi ${ }^{1} \mathrm{H}$-NMR dan FT-IR. Kedua-dua kopolimer MPEG-PbAE A dan B juga telah disintesis dan dicirikan. Sebagai kesimpulan, kopolimer MPEG-PbAE A yang terbentuk daripada monomer heksilamina linear mempunyai nombor-purata berat molekul, $M_{n}$ sebanyak 11216 dengan indeks kepoliserakan yang rendah iaitu 1.1925 , nilai CMC yang lebih rendah iaitu $84.6 \mathrm{mg} / \mathrm{L}$ dan purata saiz miselnya yang lebih sekata iaitu 26.25 \pm 0.149 nm. Justeru, kopolimer A didapati adalah lebih sesuai sebagai pembawa ubat hidrofobik jika dibandingkan dengan kopolimer B yang terbentuk daripada heksilamina siklik.

\section{PENGHARGAAN}

Penghargaan kepada Universiti Kebangsaan Malaysia (UKM) atas bantuan kewangan dengan geran projek penyelidikan (DIP-2014-013 \& DIP-2015-009) dan juga Pusat Penyelidikan dan Instrumentasi (CRIM), UKM untuk bantuan dalam pencirian sampel.

\section{RUJUKAN}

Akinc, A., Lynn, D.M., Anderson, D.G. \& Langer, R. 2003. Parallel synthesis and biophysical characterization of a degradable polymer library for gene delivery. Journal of the American Chemical Society 125(18): 5316-5323.

Ayre, A.P., Kadam, V.J., Dand, N.M. \& Patel, P.B. 2013. Polymeric micelles as a drug carrier for tumor targeting. Chronicles of Young Scientists 4(2): 94-101.

Bui, Q.N., Li, Y., Jang, M.S., Huynh, D.P., Lee, J.H. \& Lee, D.S. 2015. Redox- and $\mathrm{pH}$-sensitive polymeric micelles based on poly( $\beta$-Amino Ester)-grafted disulfide methylene oxide poly(ethylene glycol) for anticancer drug delivery. Macromolecules 48(12): 4046-4054.

Cho, H., Lai, T.C., Tomoda, K. \& Kwon, G.S. 2014. Polymeric micelles for multi-drug delivery in cancer. AAPS PharmSciTech. 16(1): 10-20.

Gaucher, G., Dufresne, M.H., Sant, V.P., Kang, N., Maysinger, D. \& Leroux, J.C. 2005. Block copolymer micelles: Preparation, characterization and application in drug delivery. Journal of Controlled Release: Official Journal of the Controlled Release Society 109(1-3): 169-188.

Hoffman, A.S. \& Pun, S.H. 2012. Pegylation of drugs and nanocarriers. In Biomaterials Science. 3rd ed., edited by Ratner, B.D., Hoffman, A.S., Schoen, F.J. \& Lemons, J.E. Oxford: Academic Press. p. 1028.

Hwang, S.J., Kim, M.S., Han, J.K., Lee, D.S., Park, H.J. \& Kim, J.S. 2007. pH-sensitivity control of PEG-Poly( $\beta$-Amino Ester) block copolymer micelle. Macromolecular Research 15(5): 437-442.

Kim, M.S., Hwang, S.J., Han, J.K., Choi, E.K., Park, H.J., Kim, J.S. \& Lee, D.S. 2006. pH-responsive PEG-Poly ( $\beta$-Amino Ester) block copolymer micelles with a sharp transition. Macromolecular Rapid Communications 27(6): 447-451.
Ko, J., Park, K., Kim,Y.S., Kim, M.S., Han, J.K., Kim, K., Park, R.W., Kim, I.S., Song, H.K., Lee, D.S. \& Kwon, I.C. 2007. Tumoral acidic extracellular $\mathrm{pH}$ targeting of $\mathrm{pH}$ responsive MPEG-Poly( $\beta$-Amino Ester) block copolymer micelles for cancer therapy. Journal of Controlled Release 123(2): 109-115.

Kwon, G.S. \& Okano, T. 1996. Polymeric micelles as new drug carriers. Advanced Drug Delivery Reviews 21(96): 107-116.

Lavasanifar, A., Samuel, J. \& Kwon, G.S. 2002. Poly(Ethylene oxide)-block-poly(L-Amino acid) micelles for drug delivery. Adv. Drug Deliv. Rev. 54(2): 169-190.

Lynn, D.M., Anderson, D.G., Putnam, D. \& Langer, R. 2001. Accelerated discovery of synthetic transfection vectors: Parallel synthesis and screening of a degradable polymer library. Journal of the American Chemical Society 123(33): 8155-8156.

Lynn, D.M. \& Langer, R. 2000. Degradable poly(Beta-Amino Esters): Synthesis, characterization, and self-assembly with plasmid DNA. J. Am. Chem. Soc. 122(10): 10761-10768.

Min, K.H., Kim, J.H., Bae, S.M., Shin, H., Kim, M.S., Park, S., Lee, H., Park, R.W., Kim, I.S., Kim, K., Kwon, I.C., Jeong, S.Y. \& Lee, D.S. 2010. Tumoral acidic pH-responsive MPEG-Poly( $\beta$-Amino Ester) polymeric micelles for cancer targeting therapy. Journal of Controlled Release 144(2): 259-266.

Movassaghian, S., Merkel, O.M. \& Torchilin, V.P. 2015. Applications of polymer micelles for imaging and drug delivery. Wiley Interdisciplinary Reviews: Nanomedicine and Nanobiotechnology 7(5): 691-707.

Peng, T., Li, Y., Ahn, D., Kim, B.S. \& Lee, D.S. 2013. Synthesis and characterization of $\mathrm{pH}$-responsive poly(2-Hydroxyethyl Aspartamide)-G-Poly( $\beta$-Amino Ester) graft copolymer micelles as potential drug carriers. Macromolecular Research 21(4): 400-405.

Stuart, B.H. 2004. Infrared Spectroscopy: Fundamentals and Applications. New York: John Wiley \& Sons Ltd.

Wu, Xiang Lan, Jong Ho Kim, Heebeom Koo, Sang Mun Bae, Hyeri Shin, Min Sang Kim, Byung Heon Lee, Park, R.W., Kim, I.S., Choi, K., Kwon, I.C., Kim, K. \& Lee, D.S. 2010 Tumor-targeting peptide conjugated $\mathrm{pH}$-responsive micelles as a potential drug carrier for cancer therapy. Bioconjugate Chemistry 21(2): 208-213.

Zhang, Y., Huang, Y. \& Li, S. 2014. Polymeric micelles: Nanocarriers for cancer-targeted drug delivery. AAPS PharmSciTech 15(4): 862-871.

Zhao, H., Duong, H.H. \& Yung, L.Y. 2010. Folate-conjugated polymer micelles with $\mathrm{pH}$-triggered drug release properties. Macromolecular Rapid Communications 31(13): 1163 1169.

Jia-Chyi Wong, Chin-Hua Chia* \& Sarani Zakaria Pusat Pengajian Fizik Gunaan, Fakulti Sains dan Teknologi Universiti Kebangsaan Malaysia 43600 Bangi, Selangor Darul Ehsan Malaysia

Swee-Yee Chin

International Medical University (IMU) 57000 Kuala Lumpur, Wilayah Persekutuan Malaysia 
Poi-Sim Khiew

Jabatan Kejuruteraan Kimia, Fakulti Kejuruteraan Universiti Nottingham Kampus Malaysia

43500 Semenyih, Selangor Darul Ehsan

Malaysia
*Pengarang untuk surat-menyurat; email: chia@ukm.edu.my

Diserahkan: 4 Mei 2016

Diterima: $\quad 8$ Ogos 2016 